\section{Ambered Kernels in Stenospermocarpic Fruit of Eastern Black Walnut}

\author{
Michele R. Warmund ${ }^{1}$ \\ Division of Plant Sciences, University of Missouri, 1-31 Agriculture Building, \\ Columbia, MO 65211
}

\author{
J.W. Van Sambeek \\ USDA Forest Service, Northern Research Station, Columbia, MO 65211
}

Additional index words. cotyledon, embryo abortion, Juglans nigra, nut size, pellicle

\begin{abstract}
Ambers" is a term used to describe poorly filled, shriveled eastern black walnut (Juglans nigra L.) kernels with a dark brown or black-colored pellicle that are unmarketable. Studies were conducted to determine the incidence of ambered black walnut kernels and to ascertain when symptoms were apparent in specific tissues. The occurrence of ambered kernels was evaluated in fruit harvested from mature 'Football' trees growing at three sites within a commercial black walnut orchard in 2008 to 2010 . Mature walnut fruit sampled from trees at Site 2 had greater odds for ambered kernels than those on trees at two other sites within the same orchard with $27 \%$ of the walnuts sampled exhibiting symptoms when examined in October. Also, black walnut fruit in 2010 had more ambered kernels than those examined in Oct. 2008 or 2009. Cropload, soil type, ambient temperatures, or precipitation was not apparently associated with a high incidence of ambered kernels. When black walnut fruit from trees at Site 2 were examined from 25 June to 6 Oct. 2011, embryos were visible in $50 \%$ of the fruit without discoloration on the first date. Stenospermocarpy (e.g., aborted or rudimentary embryos after fertilization) was observed in fruit with discolored or ambered kernels as early as 7 July. Stenospermocarpic fruit with ambered kernels had shorter embryo axis lengths (root apex to shoot apex) than fruit with non-ambered kernels on 7 July and at successive sampling dates. Cotyledon widths of ambered kernels in stenospermocarpic fruit were narrower than those of non-ambered kernels on 21 July, but symptomatic cotyledons continued to enlarge until 15 Sept. All fruit enlarged during the growing season and nut diameters varied by only $3.4 \mathrm{~mm}$ at harvest. Thus, visible embryo degeneration, which was associated with ambered kernels in black walnut fruit, was detected in early July when shell hardening occurs and kernel tissues are enlarging.
\end{abstract}

Black walnut (Juglans nigra L.) is native to much of the eastern United States and is highly valued for its nuts and timber. Black walnut trees are monoecious with one to four pistillate flowers in a cluster at distal ends of the current season's shoots. Each pistillate flower produces one orthotropous ovule surrounded by the integument (Schaffer et al., 1996). Within the ovule, an eight-nucleate embryo sac is formed. Staminate flowers generally have 20 to 30 sessile stamens and occur on catkins that emerge from dormant buds on the previous season's growth above leaf scars (Beineke and Masters, 1977). Most commercially grown black walnut cultivars are protogynous with pistillate bloom in late April to early May and pollen shed usually a few days thereafter in Missouri (Warmund and Coggeshall, 2010). After flowers are wind-pollinated, fertilization occurs 2 to $5 \mathrm{~d}$

Received for publication 17 Apr. 2014. Accepted for publication 24 June 2014.

Contribution from the Missouri Agricultural Station project 322 .

${ }^{1}$ To whom reprint requests should be addressed; e-mailwarmundm@missouri.edu. kernels have lower oil content than non-shriveled kernels. In a later study, Mangoff (1980) found that ambered kernels typically had less stearic and oleic acid than non-ambered kernels. Gibson and Kearby (1976) reported that ambered kernels were not associated with feeding by walnut husk maggots (Rhagoletis completa Cresson) in the fall. More recently, ambered kernels were found in shelled nuts of all cultivars examined, including 'Emma K', 'Kwik Krop', 'Sparrow', 'Surprise', 'Schessler', 'Davidson', 'Thomas', 'Sparks 127', 'Hare', 'Tomboy', and 'Bowser', in a black walnut repository at New Franklin, MO (Biggs, 2011). At another site, it was discovered that not all fruit produced on a single terminal fruiting shoot (with apparently healthy foliage) had ambered kernels on 'Football' trees, which suggests that these symptoms are not associated with a nutritional disorder (M.R. Warmund, unpublished data).

Other nut tree species produce discolored kernels, although causal agents are likely different from that for ambered black walnut kernels. Persian walnut cultivars such as 'Ashley', 'Serr', and 'Chico' produce fruit containing "oilless" nuts with dark, shriveled kernels in the shaded interior of the tree canopy early in the growing season (Grant et al., 1985). Unlike black walnut, Persian walnut fruiting shoots with oilless nuts produce sparse leaves with interveinal chlorosis and these fruiting spurs often die the next winter (Grant et al., 1985). Necrosis has also been reported on the basal area of pecan kernels and it affects certain cultivars such as 'Pawnee', 'Choctaw', and 'Oklahoma' more so than 'Cheyenne' (Smith et al., 2007). Although the cause of pecan kernel necrosis is unknown, it does not appear to be the result of stink bug damage, pecan weevil feeding, or a nutritional disorder.

Because of the paucity of information on black walnut ambers, the objectives of this study were to: 1) evaluate the incidence of ambered kernels in fruit of 'Football' trees at three sites within a black walnut orchard; 2) determine when symptoms of ambered kernels first appear during the growing season; and 3) ascertain which fruit tissues are associated with ambers.

\section{Materials and Methods}

especially drought (Crane, 1949). Black walnut fruit generally attain most of their size by mid-August and kernel fill is completed by late September or early October (Brawner and Warmund, 2008; Funk, 1979). Fruit are then harvested, hulled, and dried in-shell before cracking for commercial sales.

Ambers is a commonly used term for poorly filled, shriveled kernels with a dark brown or black-colored pellicle inside black walnut fruit (Funk, 1979; Gibson and Kearby, 1976) (Fig. 1). Walnuts with ambered kernels are unmarketable, resulting in economic loss to commercial growers (Biggs, 2011). Although symptoms of ambered kernels have been previously described, there has been limited research on the cause of this problem. Stoke (1941) reported that shriveled black walnut
Hourly temperature and precipitation data for 2008 to 2011 were obtained from a National Weather Service Cooperative weather station located $\approx 7 \mathrm{~km}$ from the study site. Mean maximum and minimum daily temperatures and precipitation for each month were calculated from these data.

Annual walnut production and incidence of ambered kernels. At each of three sites within a commercial orchard near Windsor, MO, five 'Football' black walnut trees on seedling $J$. nigra rootstock were selected for this study based on similarity in tree age (32 years old), size, and cropload. Trees at each site were spaced $6.1 \mathrm{~m}$ apart in a single row in a north-south row orientation. Soils at Sites 1 and $2, \approx 50 \mathrm{~m}$ apart, were classified as 
a Mandeville silt loam (fine-loamy, mixed, superactive, mesic typic hapludalfs) (Grogger and Persinger, 1976). Site 3 (located $500 \mathrm{~m}$ north of Site 2) was a Deepwater silt loam (fine-silty, mixed, superactive, thermic typic arguidolls). Fertilizer (13N-5.7P-10.8K) was applied underneath the tree canopies annually in February at $22.7 \mathrm{~kg} \cdot \mathrm{ha}^{-1}$. Trees received only natural rainfall and the sparse fescue [Schedonorus arundinaceus (Schreb.) Dumort.] groundcover was mowed as needed. No pesticides were applied to any of the trees in the orchard. Fruit were harvested from trees on 5, 6, and 7 Oct. 2008, 2009, and 2010, respectively, using a grower-designed tree shaker and then collected from the ground using a manual device (Nut Wizard; Holt's Nut Wizard, Inc., Douglas, GA). Immediately after harvest, fruit from each tree were hulled with a locally produced machine (Lane, 2000) and further cleaned using an electric bench grinder with a 15.2-cm-diameter wire brush. Hulled nuts were then stored at $4{ }^{\circ} \mathrm{C}$ for 1 week before evaluation. The number of walnuts harvested per tree was recorded. One hundred walnuts per tree were randomly sampled, bisected perpendicular to the suture using a band saw, and individually scored for the presence or absence of an ambered kernel.

Fruit yield data were subjected to an analysis of variance (ANOVA) using the PROC MIXED procedure of SAS (Version 9.2; SAS Institute, Cary, NC) for a completely randomized repeated measures design. Means were separated by Fisher's protected least significant difference test (LSD; $P \leq 0.05$ ). Data for the presence or absence of ambered kernels were subjected to the GLIMMIX procedure of SAS with a logit link function for a beta distribution. Odds were calculated to estimate the probability of ambered kernels in walnuts for each site and year. Differences among odds were determined using the LSMEANS statement $(P \leq 0.05)$. To estimate percent ambered kernels, odds were calculated from the antilog of the logit value and back-transformed $[\%$ ambered kernels = odds/(1 + odds $)]$.

Seasonal development of ambered and non-ambered kernels. Because of low numbers of fruit on black walnut trees in 2011 (an "off" production year), 24 fruit were randomly sampled from four trees located at Site 2 on seven dates (25 June, 21 July, 4 and 18 Aug., 1 and 15 Sept., and 6 Oct.). A manual fruit picker (LRB 189; Flexrake, Temple City, CA) with a 4-m-long handle was used from the ground to randomly collect fruit from the lower portion of the tree canopies. For each date, fruit diameters were measured immediately after sampling using a digital caliper (Series 500; Mitutoya America, Aurora, IL) before bisecting them to remove cotyledons and expose the embryo. Cotyledon widths and embryo axis lengths (root apex to shoot apex) (Fig. 2) were measured similarly under a stereomicroscope (Leica M205 FA; Leica Microsystems, Wetzlar, Germany) and the presence or absence of ambered kernels was then recorded. Fruit diameter, cotyledon, embryo axis, and ambers data from all sampling dates, except June when few embryos were visible, were subjected to ANOVA using a completely randomized design and a factorial arrangement of ambers and sampling date. Data were analyzed using the PROC MIXED procedure of SAS and means were separated with Fisher's protected LSD test $(P \leq 0.05)$.

On 6 Oct. 2011, all remaining fruit from each of the four trees at Site 2 were harvested, hulled, cleaned, and stored at $4{ }^{\circ} \mathrm{C}$ as described previously. Fifty walnuts from each tree were randomly selected, bisected on a band saw, and nut diameters (measured perpendicular to the suture), cotyledon widths, and embryo axis lengths were recorded. Severity of ambers symptoms for each kernel was evaluated using a 1 to 5 rating scale $(1=$ plump kernel, no visible shriveling or discoloration of tissue; $2=1 \%$ to $33 \%$ kernel shriveling; $3=34 \%$ to $66 \%$ kernel shriveling with moderately discolored tissue; $4=67 \%$ to $99 \%$ kernel shriveling with discolored tissues; $5=100 \%$ of kernel non-filled, black shriveled pellicle with discolored internal tissues). Data were subjected to ANOVA using a randomized complete block design with individual trees as blocks and ambers ratings as treatments. Data were analyzed using the PROC MIXED procedure of SAS and means were separated with Fisher's protected LSD test $(P \leq 0.05)$.

\section{Results}

In Apr. 2010, the mean maximum daily temperature was relatively warmer than that

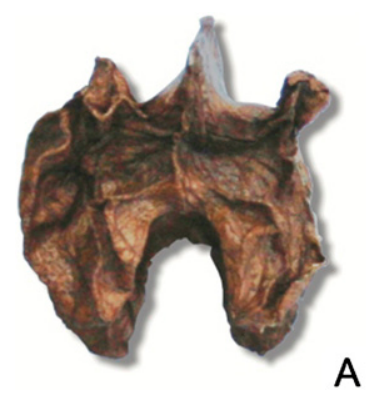

A

Fig. 1. (A) Ambered and (B) non-ambered black walnut kernels.

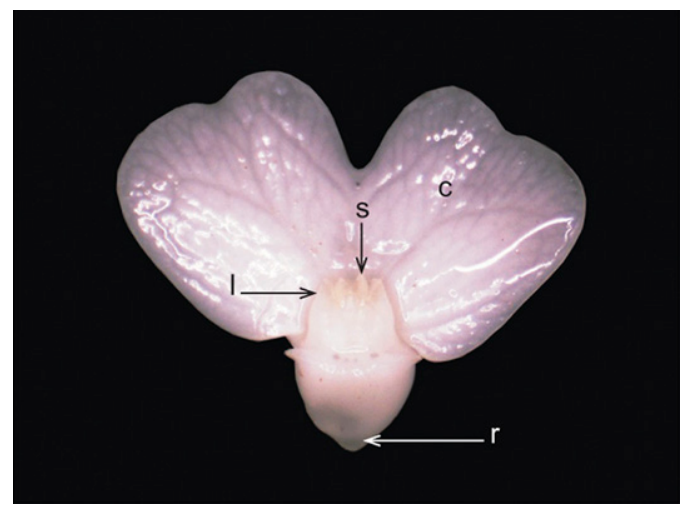

Fig. 2. Cotyledon (c), embryo axis, measured from root apex (r) to shoot apex (s), and leaf primordia (l) in a developing 'Football' black walnut kernel collected on 7 July 2011.

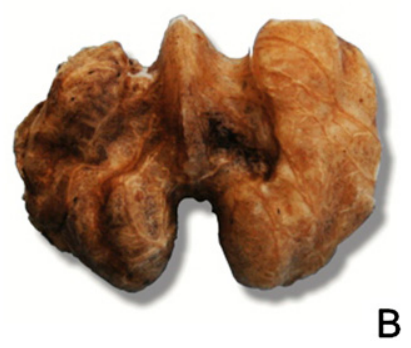

for the same month in other years (Fig. 3). Also, mean maximum daily temperatures were always warm in July and August, ranging from 28 to $35^{\circ} \mathrm{C}$. In Aug. 2010, the average maximum daily temperature was slightly warmer than that for August of other years. Additionally, July 2011 was warm as compared with the same time in other years. Precipitation during the period of fruit growth (June through September) was 725 , 503, 576, and $328 \mathrm{~mm}$ in 2008, 2009, 2010, and 2011, respectively (Fig. 3). Precipitation during June 2010 was only $60 \mathrm{~mm}$, which is historically (1985 to 2010) $69 \mathrm{~mm}$ below normal for that month (P. Guinan, unpublished data). However, monthly precipitation after June 2010 was not unusually low. Visible symptoms of drought stress (leaf wilting, fruit shriveling, or drop) were absent during all growing seasons.

Annual walnut production and incidence of ambered kernels. Site 1 in 2010 had more fruit per tree than other sites in all years except for Site 1 in 2008 (Table 1). Site 1 in 2009 also had fewer fruit per tree than other sites in all years except for Site 3 in 2009. When kernels were examined, walnuts from Site 2 had greater odds for ambered kernels than those from the other two sites (Table 2). Thus, $27 \%$ of the sampled walnuts from Site 2 had ambered kernels, whereas those from Sites 1 and 3 had $6 \%$ and $10 \%$ ambered kernels, respectively. Also, walnuts collected in 2010 had greater odds of having ambered kernels than those harvested in 2008 or 2009. In $2010,21 \%$ of the walnuts had ambered kernels, whereas $\approx 9 \%$ of those sampled in other years had ambered kernels.

B 


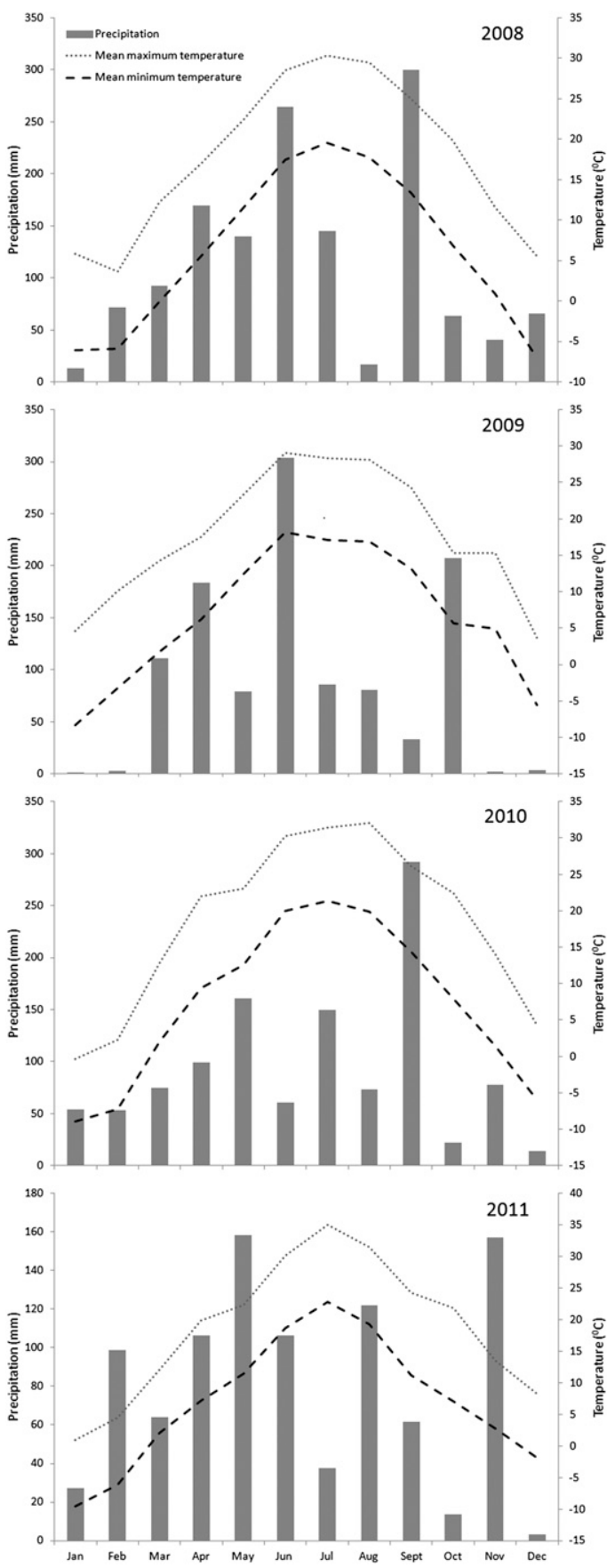

Fig. 3. Mean maximum and minimum daily temperatures and precipitation for each month near Windsor, MO, in 2008, 2009, 2010, and 2011.

Seasonal development of ambered and non-ambered kernels. On 25 June 2011, embryos were visible in only $50 \%$ of the fruit examined and nearly all were less than $1.5 \mathrm{~mm}$ long (data not shown). Ambers symptoms, including embryo or cotyledon discoloration, were not observed at this early date. By 7 July, embryos were found in all walnuts, but embryo axes in ambered kernels were shorter ( $0.8 \mathrm{~mm}$ long) than those in non-ambered kernels (2.3 mm long) (Fig. 4). Thereafter, embryo axes lengths in fruit with ambered kernels elongated only slightly (less than $1.2 \mathrm{~mm}$ long) and were statistically similar at all sampling dates. In contrast, embryo axis lengths in nuts with non-ambered kernels in- creased in size from 7 July to 18 Aug. and were similar thereafter. At all sampling dates, embryos and cotyledons in ambered kernels ranged from slightly off-colored to dark brown or black (Fig. 5). Cotyledon widths of ambered and non-ambered kernels were similar on 7 July, but those of ambered kernels were always smaller than cotyledons of non-ambered kernels at subsequent dates (Fig. 4). Moreover, cotyledons of ambered kernels only grew $\approx 4 \mathrm{~mm}$ wider from early July to 6 Oct., whereas those of non-ambered kernels enlarged by $\approx 18 \mathrm{~mm}$ during the same time.

'Football' fruit with ambered kernels had a smaller diameter than those with non-ambered kernels across all sampling dates (Table 3).
Table 1. Mean number of 'Football' black walnut fruit harvested per tree from three sites in an orchard near Windsor, MO, in 2008, 2009, and 2010 .

\begin{tabular}{ccc}
\hline Site $^{\mathrm{z}}$ & Year $^{\mathrm{y}}$ & $\begin{array}{c}\text { No. of } \\
\text { walnuts }\end{array}$ \\
\hline 1 & 2008 & $949 \mathrm{ab}$ \\
2 & 2008 & $759 \mathrm{bc}$ \\
3 & 2008 & $487 \mathrm{~cd}$ \\
& & \\
1 & 2009 & $29 \mathrm{e}$ \\
2 & 2009 & $425 \mathrm{~cd}$ \\
3 & 2009 & $174 \mathrm{de}$ \\
& & \\
1 & 2010 & $1153 \mathrm{a}$ \\
2 & 2010 & $541 \mathrm{~cd}$ \\
3 & 2010 & $602 \mathrm{c}$
\end{tabular}

Significance $^{\mathrm{w}}$

Site

Year

Site $\times$ year

NS

${ }^{\mathrm{z}}$ Soils at Sites 1 and 2 were classified as a Mandeville silt loam and soil at Site 3 was a Deepwater silt loam.

${ }^{y}$ Nuts were harvested on 5, 6, and 7 Oct. 2008, 2009 , and 2010, respectively.

${ }^{x}$ Values represent the mean of four trees per site. Means followed by different letters are significantly different $(P \leq 0.05)$.

${ }_{\mathrm{wS}}$, *** indicate nonsignificance and statistical significance at $P \leq 0.001$, respectively.

Table 2. Odds and percentage of 'Football' black walnuts that had ambered kernels at harvest at three sites in an orchard near Windsor, MO, in 2008, 2009, and 2010. ${ }^{\mathrm{z}}$

\begin{tabular}{ccc}
\hline & $\begin{array}{c}\text { Odds of } \\
\text { ambered kernels }^{\mathrm{y}}\end{array}$ & $\begin{array}{c}\text { Ambered } \\
\text { kernels (\%) }\end{array}$ \\
\hline Site $^{\mathrm{x}}$ & $0.07 \mathrm{~b}$ & 6.4 \\
1 & $0.38 \mathrm{a}$ & 27.4 \\
2 & $0.11 \mathrm{~b}$ & 9.8 \\
3 & & \\
Year & & 9.1 \\
2008 & $0.10 \mathrm{~b}$ & 8.7 \\
2009 & $0.09 \mathrm{~b}$ & 21.1 \\
2010 & $0.27 \mathrm{a}$ & \\
Significance & & \\
Site & & \\
Year & $* * *$ & \\
Site $\times$ year & $* * *$ & \\
\hline
\end{tabular}

${ }^{\mathrm{z}}$ Harvest dates were 5, 6, and 7 Oct. 2008, 2009, and 2010 , respectively.

${ }^{y}$ Values represent 100 nuts sampled from each of five trees at each location. Odds were calculated from the antilog of the logit value and back transformed $[\%$ ambered kernels $=$ odds $/(1+$ odds)] to estimate percent ambered kernels. Mean differences among odds were determined using the LSMEANS statement of SAS. Odds followed by different letters within the column are significantly different for sites and years with no significant interaction of site $\times$ year $(P \leq 0.05)$.

${ }^{x}$ Soils at Sites 1 and 2 were classified as a Mandeville silt loam and soil at Site 3 was a Deepwater silt loam.

${ }_{\mathrm{NS}}$, *** indicate nonsignificance and statistical significance at $P \leq 0.001$, respectively.

Mean diameters of fruit with ambered and non-ambered kernels increased significantly in July ( 28 to $39 \mathrm{~mm}$ ) with more gradual enlargement until 6 Oct. when fruit diameter averaged $51 \mathrm{~mm}$. 

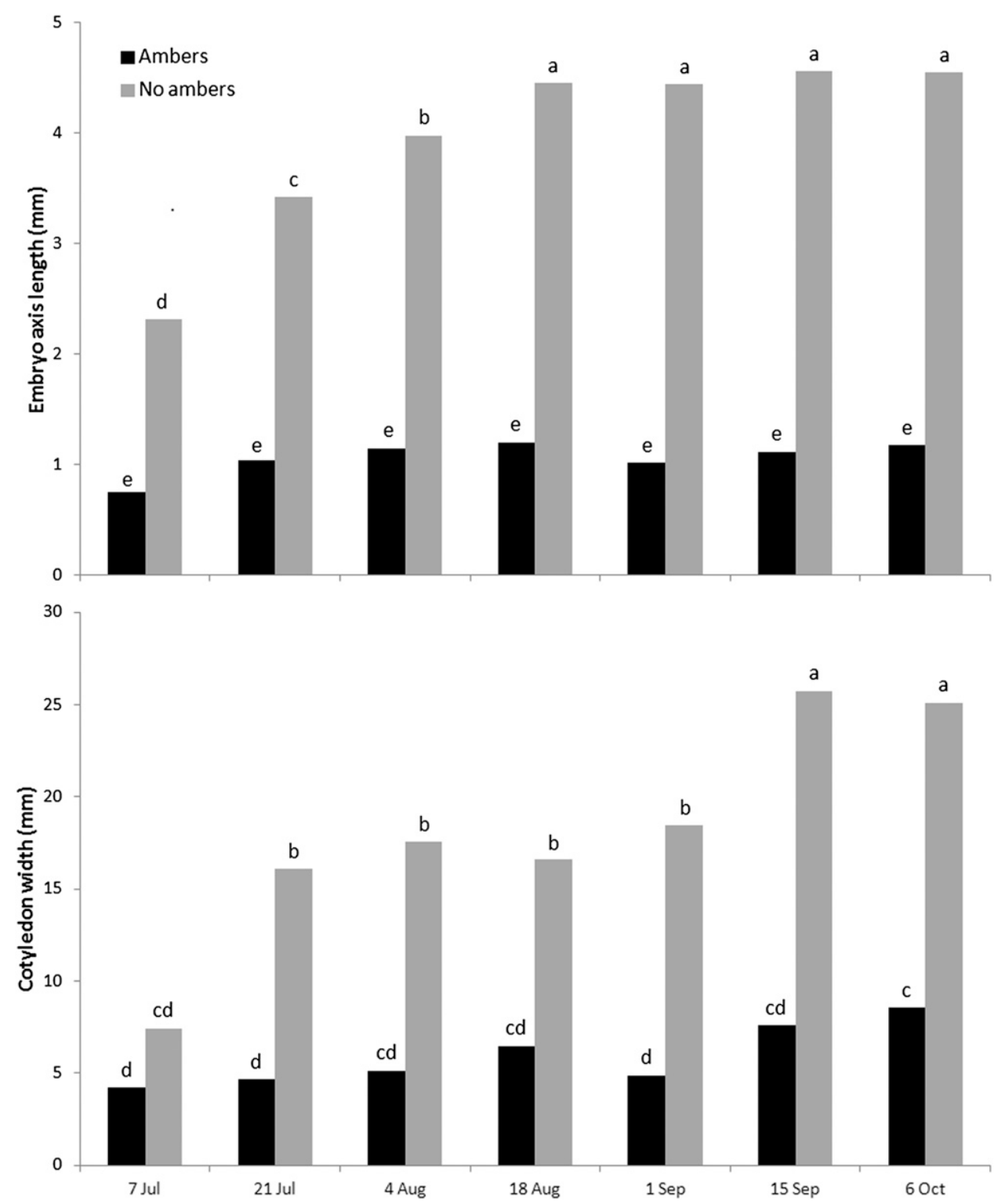

Fig. 4. Mean embryo axis lengths and cotyledon widths of ambered and non-ambered 'Football' black walnut kernels collected from Site 2 on 7 and 21 July, 4 and 18 Aug., 1 and 15 Sept. and 6 Oct. 2011 (24 fruit per sampling date). Means with different letters were significantly different by Fisher's protected least significant difference test, $P \leq 0.05$.

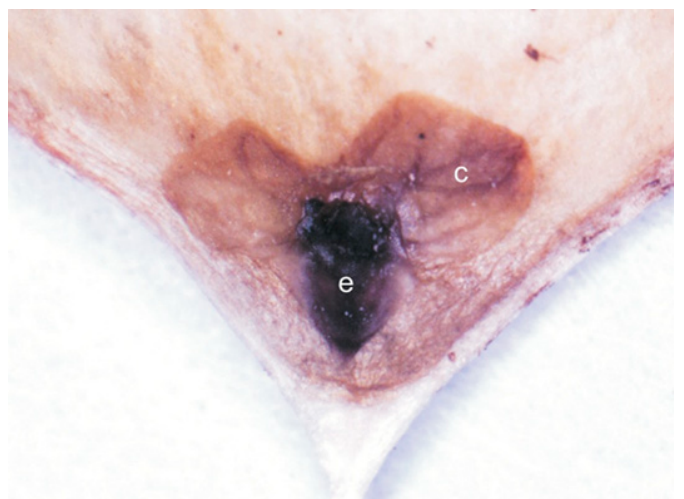

Fig. 5. Embryo (e) and cotyledon (c) of an ambered 'Football' black walnut kernel sampled on 21 July 2011 from an orchard near Windsor, MO.

When mature nuts were evaluated, amber symptoms ranged from plump kernels with no discoloration to non-filled kernels with necrotic tissue. The total number of kernels increased, embryo axis lengths decreased (Table 4). Embryo axis lengths in kernels with 1, 3 , and 5 ratings averaged 5.3,3.5, and $1.3 \mathrm{~mm}$, respectively. Mean cotyledon widths of kernels with 1 or 2 ratings were wider than those of nuts assigned 3, 4, or 5 ratings. Hulled nut diameters for walnuts with light-colored, plump kernels to severely ambered kernels varied by only $3.4 \mathrm{~mm}$. However, nuts with kernel ratings of 1 or 2 were wider than those with ratings of 4 and 5 (Table 4 ).

\section{Discussion}

'Football' black walnut fruit numbers per tree were similar among all sites when averaged across three years of this study (Table 1). Deepwater (Site 3) and Mandeville silt loam soils (Sites 1 and 2) have water-holding capacities of 30.0 and $22.5 \mathrm{~cm}$, respectively, in the upper $1.5 \mathrm{~m}$ of soil (R.J. Miles, unpublished data). Despite their different soil water-holding 
capacities, non-irrigated trees produced similar fruit numbers over a 3-year period. However, mean fruit numbers varied by location and year, indicating that other factors influenced fruit yields. Black walnut trees typically have an irregular fruiting habit with individual trees within an orchard bearing large crops erratically (Funk, 1979). High fruit numbers at Site 1 in 2008 and 2010 indicated a strong biennial fruiting tendency for these 'Football' trees, whereas fruit numbers fluctuated annually to a lesser extent at Sites 2 and 3. Reid et al. (2009) listed 'Football' as one of several black walnut cultivars with a high tendency for alternate bearing. Also, low yields of walnuts have been associated with fruit drop caused by black walnut curculio [Conotrachelus retentus (Say)] larvae feeding on young fruit in late May and early June (Blair, 1978; Schreiber and Linit, 1991). In our study, usually less than 20 curculio-damaged fruit were observed underneath each tree during each growing season (data not shown).

After pollination, fertilization, and "June drop" (unfertilized fruit shed from trees), discolored embryos, often with shriveled cotyledons, were visible inside fertilized fruit

Table 3. Mean 'Football' black walnut fruit diameters of ambered and non-ambered samples collected from trees at Site 2 in an orchard near Windsor, $\mathrm{MO}$, on various dates in 2011.

\begin{tabular}{|c|c|}
\hline & Fruit diam $(\mathrm{mm})$ \\
\hline \multicolumn{2}{|l|}{ Kernel type $^{z}$} \\
\hline Ambered & $38 \mathrm{~b}$ \\
\hline Non-ambered & $48 \mathrm{a}$ \\
\hline \multicolumn{2}{|l|}{ Date } \\
\hline 7 July & $28 \mathrm{~d}$ \\
\hline 21 July & $39 \mathrm{c}$ \\
\hline 4 Aug. & $42 \mathrm{bc}$ \\
\hline 18 Aug. & $46 \mathrm{~b}$ \\
\hline 1 Sept. & $44 \mathrm{~b}$ \\
\hline 15 Sept. & $45 \mathrm{~b}$ \\
\hline 6 Oct. & $51 \mathrm{a}$ \\
\hline \multicolumn{2}{|l|}{ Significance $^{\mathrm{y}}$} \\
\hline Kernel type & $* * *$ \\
\hline Date & $* * *$ \\
\hline Kernel type $\times$ date & NS \\
\hline \multicolumn{2}{|c|}{ 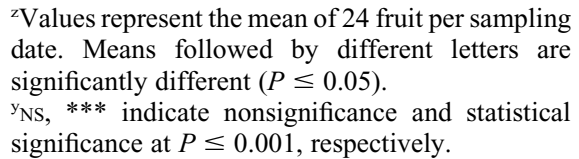 } \\
\hline
\end{tabular}

Table 4. Mean embryo axis length, cotyledon width, and hulled nut diameter of 'Football' black walnuts for each ambers rating of kernels harvested at Site 2 in an orchard near Windsor, MO, on 6 Oct. $2011 .{ }^{2}$

\begin{tabular}{|c|c|c|c|}
\hline & Embryo axis length & Cotyledon width & Hulled nut diam \\
\hline Kernel rating ${ }^{\mathrm{y}}$ & $\ldots \ldots \ldots \ldots \ldots \ldots$ & $\ldots(\mathrm{mm}) \ldots \ldots$ & $\ldots \ldots \ldots \ldots$ \\
\hline $1(52)$ & $5.32 \mathrm{a}$ & $26.9 \mathrm{a}$ & $32.8 \mathrm{a}$ \\
\hline $2(34)$ & $4.47 \mathrm{~b}$ & $23.9 \mathrm{a}$ & $32.4 \mathrm{ab}$ \\
\hline $3(37)$ & $3.48 \mathrm{c}$ & $18.2 \mathrm{~b}$ & $30.9 \mathrm{bc}$ \\
\hline $4(23)$ & $2.97 \mathrm{~d}$ & $15.5 \mathrm{~b}$ & $30.3 \mathrm{c}$ \\
\hline $5(54)$ & $1.34 \mathrm{e}$ & $6.4 \mathrm{c}$ & $29.4 \mathrm{~d}$ \\
\hline
\end{tabular}

${ }^{2}$ Values represent means of 50 black walnuts from each of four trees. Means within columns followed by different letters are significantly different $(P \leq 0.05)$.

${ }^{\mathrm{y}}$ Ambers ratings of kernels $(1=$ plump kernel, no visible shriveling or discoloration of tissue; $2=1 \%$ to $33 \%$ kernel shriveling; $3=34 \%$ to $66 \%$ kernel shriveling with moderately discolored tissue; $4=67 \%$ to $99 \%$ kernel shriveling with discolored tissues; $5=100 \%$ of kernel non-filled, black shriveled pellicle with discolored internal tissues). Values in parentheses represent the total number of kernels for each rating.
$10 \%$ shriveled kernels with dark-colored pellicles in Beltsville, MD (Berry, 1960). However, in a similar study at Fredericksburg, VA, black walnut kernel filling and pellicle color were unaffected when 'Stabler' trees with a light cropload were prematurely defoliated by an anthracnose infection (Berry, 1960). In a 2003 study evaluating the relative anthracnose defoliation of 13 black walnut cultivars, 'Football' trees ranked high for susceptibility and 'Sparrow' trees ranked low for this disease (Reid et al., 2004). 'Sparrow' trees had greater than $60 \%$ ambered kernels in 2007, although trees were not prematurely defoliated by anthracnose (M.R. Warmund, unpublished data).

Stenospermocarpy is a term to describe the development of fruit that contain an aborted or a rudimentary embryo after pollination and fertilization. This term was first used by Stout (1936) to characterize seedless grape cultivars such as 'Thompson Seedless' (Vitis vinifera L.), in which the fruit has an aborted embryo or contains a seed trace. In these grape cultivars, fertilization occurred before stenospermocarpic fruit developed. Stenospermocarpy also occurs in several other fruits, including 'Fuerte' and 'Ettinger' avocado (Persea americana Mill) (Tomer et al., 1980), 'Nuomici' litchi (Litchi chinensis Sonn.) (Xiang et al., 2001), and Citrus kinokuni hort. ex Tanaka 'Mukaku Kishu' (Yamasaki et al., 2007). In seedless avocados, degenerated embryo and endosperm tissues were visible at different stages of fruit development as well as a few intact embryos (Tomer et al., 1980). Filbert (Corylus avellana L.) trees often produce seedless nuts or "blanks" (Lagerstedt, 1977). Small-seeded or "semi-blank" pistachio (Pistacia vera L.) fruit, with post-fertilization cotyledon degeneration during late stages of fruit development, have also been reported (Shuraki and Sedgley, 1996). Reduced embryo lengths and cotyledon widths found in ambered black walnut kernels may be analogous to modified tissues in seedless avocado, filbert, and "semi-blank" pistachio. As implicated for seedless filbert (Lagerstedt, 1977), the cause of ambers in black walnut may be the result of genetic incompatibility, aneuploidy, or other unknown factors. The varying range of black walnut ambers symptoms in Oct. 2011 indicates that self-pollination is not the sole cause of ambers (Table 4).

Recently, researchers identified a single dominant gene to breed seedless citrus fruits and molecular approaches have been used to induce embryo abortion for seedless fruits in several other horticultural crops (Callahan et al., 2011; Chavez and Chaparro, 2011; Lora et al., 2011). In our study, the presence of necrotic and undersized embryos in black walnut fruit in July and thereafter indicate that stenospermocarpy also occurs in this genus. Additionally, fruit enlargement is not dependent on embryo enlargement, even when shriveled kernels with dark brown pellicles are produced (i.e., ambered kernels). To our knowledge, genetic expression of stenospermocarpy has not been investigated in black walnut fruit 
but may provide useful information regarding ambered kernels in the future.

In conclusion, stenospermocarpy occurred in developing 'Football' black walnut fruit. Aborted or small degenerated embryos in stenospermocarpic black walnut were observed in fruit by early July and at subsequent sampling dates throughout the growing season. Stenospermocarpic fruit also had reduced cotyledon widths by 21 July. During the growing season, stenospermocarpic fruit enlarged and contained incompletely or non-filled kernels with shriveled, dark brown or black-colored pellicles. Stenospermocarpic fruit also had slightly smaller nut diameters than those with filled kernels and light-colored pellicles at harvest. Thus, stenospermocarpic fruit, which contain unmarketable ambered kernels, are not often apparent without cracking to expose the kernel. Future studies will focus on the underlying mechanism of stenospermocarpy early in the growing season.

\section{Literature Cited}

Beineke, W.F. and C.J. Masters. 1977. Pollen maturation and extraction in black walnut. Tree Planter's Notes 28:7-9.

Berry, F.H. 1960. Etiology and control of walnut anthracnose. Univ. MD. Agr. Expt. Sta. Bul. A-113.

Biggs, A. 2011. Vegetative growth and fruiting characteristics of black walnut. MS thesis, Univ. MO., Columbia, MO.

Blair, L.M. 1978. The bionomics of the black walnut curculio and its impact on black walnut shoot development and nut production. MS thesis, Univ. MO, Columbia, MO.

Brawner, S.A. and M.R. Warmund. 2008. Husk softening and kernel characteristics of three black walnut cultivars at successive harvest dates. HortScience 43:691-695.
Callahan, A., C. Dardick, and R. Scorza. 2011. Pitless plum: Reality or fantasy. Chron. Hort. 51:18-22.

Chavez, D.J. and J.X. Chaparro. 2011. Identification of markers linked to seedlessness in Citrus kinokuni hort. ex Tanaka and its progeny using bulked segregant analysis. HortScience 46:693697.

Crane, H.L. 1949. The development and filling of nuts. Northern Nut Growers Assn. Annu. Rpt. 39:130-139.

Funk, D.T. 1979. Black walnuts for nuts and timber, p. 51-73. In: Jaynes, R.A. (ed.). Nut tree culture in North America. Northern Nut Growers Assn., Hamden, CT.

Gibson, K.E. and W.H. Kearby. 1976. Black walnut nutmeat quality in relation to the presence of husk fly maggots in the husks. Northern Nut Growers Assn. Annu. Rpt. 67:109-113.

Grant, J., G.S. Sibbett, and J. Labavitch. 1985. Oilless nut biology and composition. Univ. CA, Davis, CA. 28 Feb. 2014. <http://walnutresearch. ucdavis.edu/1985/1985_37.pdf $>$.

Grogger, H.E. and I.D. Persinger. 1976. Soil survey of Henry county, Missouri. United States Dept. of Agr. Soil Conservation Serv., Washington, DC.

Lagerstedt, H.B. 1977. The occurrence of blanks in the filbert Corylus avellana L. and possible causes. Econ. Bot. 31:153-159.

Lane, B. 2000. Notes from over a quarter-century of building black walnut processing equipment. The Nutshell. Northern Nut Growers Assn. $54: 1-12$.

Lora, J., J.I. Hormaza, M. Herrero, and C.S. Gasser. 2011. Seedless fruits and the disruption a conserved genetic pathway in angiosperm ovule development. Proc. Natl. Acad. Sci. USA 108:5461-5465.

Mangoff, R.N. 1980. Nutrient content of light and amber black walnut kernels. MS thesis, Univ. MO, Columbia, MO.

Reid, W., M.V. Coggeshall, H.E. Garrett, and J. Van Sambeek. 2009. Growing black walnut for nut production. Univ. MO Ctr. for Agroforestry, Publ. AF1011.
Reid, W., M.V. Coggeshall, and K.L. Hunt. 2004. Cultivar evaluation and development for black walnut orchards. Proc. 6th Walnut Council Research Symposium. USDA Gen. Tech. Rpt. NC-243. p. $18-24$.

Schaffer, K.L., M.F. George, M. Peleg, H.E. Garrett, and R.A. Cecich. 1996. Pistillate flower development in eastern black walnut. Can. J. For. Res. 26:1514-1519.

Schreiber, A.A. and M.J. Linit. 1991. Patterns of nut mortality in a black walnut plantation with particular reference to insects. J. Kans. Entomol. Soc. 64:38-44.

Shuraki, Y.D. and M. Sedgley. 1996. Fruit development of Pistachia vera (Anacardiaceae) in relation to embryo abortion and abnormalities at maturity. Austral. J. Bot. 44:35-45.

Smith, M.W., B.S. Cheary, and B.L. Carroll. 2007. The occurrence of pecan kernel necrosis. HortScience 42:1351-1356.

Stoke, H.F. 1941. Factors influencing the color and quality of black walnut kernels. Northern Nut Growers Assoc. Annu. Rpt 32:37-41.

Stout, A.B. 1936. Seedlessness in grapes. New York State Agr. Expt. Sta. Bul. 238.

Tomer, E., G. Gazit, and D. Eisenstein. 1980. Seedless fruit in 'Fuerte' and 'Ettinger' avocado. J. Amer. Soc. Hort. Sci. 105:341-346.

Van Sambeek, J.W. and G. Rink. 1982. Physiology and silviculture of black walnut for combined timber and nut production. Northern Nut Growers Assoc. Annu. Rpt. 72:100-107.

Warmund, M.R. and M.V. Coggeshall. 2010. Flowering and fruit characteristics of black walnut cultivars at the University of Missouri repository. Acta Hort. 861:177-181.

Xiang, X., L. Ou, Y. Qiu, P. Yuan, and J. Chen. 2001. Embryo abortion and pollen parent effects in 'Nuomici' and Guiwei' litchi. Acta Hort. 558:257-260.

Yamasaki, A., A. Kitajima, N. Ohara, M. Tanaka, and K. Hasegawa. 2007. Histological study of expression of seedlessness in Citrus kinokuni 'Mukaku Kishu' and its progenies. J. Amer. Soc. Hort. Sci. 132:869-875. 